\title{
Tannic acid is not mutagenic in germ cells but weakly genotoxic in somatic cells of Drosophila melanogaster
}

\author{
Cunha, K S ; Campesato, V R ; Reguly, M L ; Gimmler-Luz, M C ; Graf, U ; de Andrade, H H R
}

\begin{abstract}
Tannic acid (TA) was tested for genotoxic activity in three different assays (1-3) in Drosophila melanogaster by feeding of larvae or adult flies. TA did not induce sex-linked recessive lethals (1) nor sex-chromosome loss, mosaicism or non-disjunction (2) in male germ cells. In the wing somatic mutation and recombination test (SMART) (3) TA was found to be toxic for larvae of the high bioactivation cross and produced a weak positive response. These results suggest that this compound, when administered orally to larvae or adults of D.melanogaster, is not mutagenic and clastogenic in male germ cells, but weakly genotoxic in somatic cells of the wing imaginal disk
\end{abstract}

DOI: https://doi.org/10.1093/mutage/10.4.291

Posted at the Zurich Open Repository and Archive, University of Zurich ZORA URL: https://doi.org/10.5167/uzh-153794

Journal Article

Published Version

Originally published at:

Cunha, K S; Campesato, V R; Reguly, M L; Gimmler-Luz, M C; Graf, U; de Andrade, H H R (1995). Tannic acid is not mutagenic in germ cells but weakly genotoxic in somatic cells of Drosophila melanogaster. Mutagenesis, 10(4):291-295.

DOI: https://doi.org/10.1093/mutage/10.4.291 


\section{Tannic acid is not mutagenic in germ cells but weakly genotoxic in somatic cells of Drosophila melanogaster}

\author{
K.S.Cunha ${ }^{1}$, V.R.Campesato ${ }^{1}$, M.L.Reguly ${ }^{1}$, \\ M.C.Gimmler-Luz ${ }^{1}$, U.Graf ${ }^{2}$ and H.H.R.de Andrade ${ }^{1,3}$
}

\begin{abstract}
'Laboratóno de Mutagênese, Departamento de Genélıca, Universidade Federal do Rio Grande do Sul, Av. Bento Gonçalves 9500, Campus do Vale, Predio 43323, Calxa Postal 15053, 91501-970 Porto Alegre RS, Brazil and ${ }^{2}$ Institute of Toxicology. Swiss Federal Institute of Technology (ETH) and University of Zürich, CH-8603 Schwerzenbach, Switzerland

${ }^{3}$ To whom correspondence should be addressed
\end{abstract}

Tannic acid (TA) was tested for genotoxic activity in three different assays (1-3) in Drosophila melanogaster by feeding of larvae or adult flies. TA did not induce sex-linked recessive lethals (1) nor sex-chromosome loss, mosaicism or non-disjunction (2) in male germ cells. In the wing somatic mutation and recombination test (SMART) (3) TA was found to be toxic for larvae of the high bioactivation cross and produced a weak positive response. These results suggest that this compound, when administered orally to larvae or adults of D.melanogaster, is not mutagenic and clastogenic in male germ cells, but weakly genotoxic in somatic cells of the wing imaginal disk.

\section{Introduction}

Tannic acid (TA) is a phenolic compound that occurs naturally in wood, bark, leaves and roots of a variety of plants, including mono- and dicotyledons (Enomoto, 1987). Several hundred tons of TA per year are prepared commercially for pharmaceutical and industrial uses [International Agency for Research on Cancer (IARC) 1976]. In the human diet it is found in beverages such as green and black tea, cocoa, coffee, red and rosé wine and beer. In addition, TA is widely used as a flavouring agent in non-alcoholic beverages, ice cream, sweets, baked goods and liquors (Bichel and Bach, 1968; Hartman and Shankel, 1990). It is estimated that the human consumption of tannins is $>1 \mathrm{~g} /$ day per person (Ramel et al., 1986).

Earlier studies suggest that TA displays acute hepatotoxic effects and can induce liver tumours and sarcomas in laboratory rodents (Korpássy and Mosonyi, 1950; Kirby, 1960; Korpássy, 1961; Bichel and Bach, 1968). In spite of these observations, no sufficient data exist which clearly indicate that TA has carcinogenic activity in humans (Enomoto, 1987).

Experimental evidence on the mutagenic or clastogenic effects of TA is scarce and controversial. There are some indications that this compound has clastogenic activity in mammalian cells both in vivo and in vitro (Sharma et al., 1982; Stich and Rosin, 1984; Stich and Dunn, 1986). A further indication for the interaction of TA with genetic material comes from the work of Szakmary and Knasmuller (1991) who found that it has mutagenic activity in somatic cells of Drosophila melanogaster.

In contrast to these findings, a large number of studies have also characterized this chemical as an antimutagenic agent acting via various mechanisms (Huang et al., 1983; Das et al., 1987; Sasaki et al., 1988, 1989, 1990; Ito et al., 1989).
Furthermore, studies done in our own laboratory have demonstrated that TA shows a co-mutagenic effect on ring- $X$ chromosome loss induced by mitomycin $\mathrm{C}$ in sperm cells of D.melanogaster (Cunha et al., 1994). The existence of conflicting results on the genotoxic effects of TA observed in different test systems prompted us to study its genotoxicity in D.melanogaster in more detail. We have tested TA in male germ cells by means of the sex-linked recessive lethal (SLRL) and the sex-chromosome loss, mosaicism and non-disjunction (RXL) assays, as well as in somatic cells by means of the wing somatic mutation and recombination test (SMART). The SMARTs using either eye or wing imaginal disk cells offer several advantages over the germ line assays. Due to the fact that they are one-generation tests, they are much faster and far less laborious than the germ line assays. The major advantage, however, is the fact that they detect not only mutagenic activity but also recombinogenic activity in somatic cells.

\section{Materials and methods}

Chemicals

Tannic acid (TA, CAS No. 1401-55-4) was purchased from Vetec Quimica Fina Ltda, São Paulo, Brazıl. It was dissolved in $003 \mathrm{M}$ phosphate buffer, $\mathrm{pH}$ 6.8, containing 5\% sucrose (Merck, Darmstadt, Germany).

Treatment of larvae

Eggs were collected over $8 \mathrm{~h}$ in culture bottles containing a solid agar base ( $5 \%$ w/v agar-agar in water) covered with a $5 \mathrm{~mm}$ thick layer of live baker's yeast supplemented with sucrose. Three days later, the larvae were washed out of the bottles using tap water and then transferred into vials containing Drosophila Instant Medium (Formula 4-24, Carolina Biological Supply Co., Burlington, NC, USA) which was rehydrated with $5 \mathrm{ml}$ of the different TA solutions. Negative buffer controls were included. The larvae were fed this medium for the rest of their development until pupation (Graf et al., 1984).

\section{Treatment of adults}

Three-day-old adult males were starved at room temperature for $4 \mathrm{~h}$ and then fed for 2 days with the different solutions using the standard feeding procedure (Wurgler et al., 1984). The solutions were renewed after $24 \mathrm{~h}$.

Genetic designations

A description of the genetic symbols used can be found in Lindsley and Zimm (1992).

\section{Sex-linked recessive lethal test}

One-day-old males (treated as larvae) or 3-day-old males (exposed as adults) from the wild-type stock Oregon $R$ were mated to virgin Basc females, and the $\mathrm{X}$ chromosomes were tested in the standard way for the presence of sexlinked recessive lethals (Würler et al., 1984). Each treated adult male was crossed to three virgin females per brood for two successive broods of 3 and 2 days duration, respectively. For the males exposed as larvae, the brooding pattern was different: each male was mated twice with a harem of three females for only 1 day (Valencia et al., 1989). The statistical evaluation of the SLRL data was performed with the conditional binomial test according to Kastenbaum and Bowman (1970) (two-sided tests, $\alpha=\beta=0.05$ ).

Sex-chromosome loss test

Males of the genotype $C(1) 2$, y $B / y^{+} Y B^{S}$, treated as larvae or as adults, were crossed to $y \boldsymbol{w} s n^{3}$ virgin females. The brood patterns used in this assay were identical to those described above. The progeny of each vial were scored separately, and the scoring continued until the 14th day after starting the cultures. The following classes of progeny were recorded, where $X_{f}$ and ring- $X_{m}$ represent $X$ chromosomes from the female and the male parent, respectively: regular females $\left(X_{p} /\right.$ ring- $\left.X_{m}\right)$ and regular males $\left(X_{f} / Y\right)$; exceptional males resulting from complete ring- $X$ loss $\left(X_{P} / 0\right)$ and from partial $Y$ 
chromosome loss $\left(\mathrm{X}_{f} / \mathrm{Y}, D f\left(B^{S} \Gamma\right)\right.$ and $\mathrm{X}_{f} / \mathrm{Y}, D f\left(y^{+} \digamma\right)$; mosaic flies resulting from complete ring- $X$ chromosome loss $\left(X_{f} /\right.$ ring- $\left.X_{m}+X_{f} / 0\right)$ and partial $Y$ chromosome loss $\left(\mathrm{X}_{f} / \mathrm{Y}+\mathrm{X}_{f} / \mathrm{Y}, D f\left(y^{+}\right)\right.$); as well as exceptional females resulting from paternal nondisjunction $\left(X_{f} /\right.$ ring $\left.-X_{m} / Y\right)$. The statistical analysis of the data was done with the conditional binomial test according to Kastenbaum and Bowman (1970) (two-sided tests, $\alpha=\beta=0.05$ ).

Somatic mutation and recombination test

In this test, a high bioactivation cross was used: ORR/ORR; $f r^{3} / I n(3 L R) T M 3$, $r^{i} p^{p}$ sep l(3)89Aa $b x^{34 e}$ e $B d^{S}$ females mated to $m w h$ males. This cross is described in Graf and van Schaik (1992) and Graf and Singer (1992). The wing spot test was performed according to the description given by Graf et al. (1984, 1989). Only the wings of trans-heterozygous individuals (mwh $\mathrm{fr}^{+} /$ $m w h^{+} f r^{3}$ ) were mounted and scored for the occurrence of spots (i.e., $m w h$ or $f r^{3}$ single spots or $m w h / f f r^{3}$ twin spots). The size of the mutant spots was determined by counting the number of mutant cells. Equal numbers of wings from female and male flies were analysed in each series, and control and treated series were always of identical size, as outlined by Fres and Würgler (1995). The evaluation of the wing spot data was performed with the computer programme SMART (F.E.Würgler, unpublished). The frequencies of total spots per wing were analysed statistically using a multiple-decision methodology (Frei and Wurgler, 1988). The conditional binomial test according to Kastenbaum and Bowman (1970) was used (two-sided, $\alpha=\beta=0.05$ ). Based on the number of $m w h$ clones, the number of wings analysed, and the number of cells scored in each wing $(-24400)$, the clone formation frequency per cell cycle and $10^{5}$ cells was calculated (for details see Frei et al., 1992a,b).

\section{Results and discussion}

In a first approach we investigated the possible genotoxic activity of TA in male germ line cells of larvae and of adults using two different assays in order to detect the mutagenic and/or clastogenic activity of TA. Table I gives the results of the SLRL test after the exposure of Oregon $R$ male larvae to $0,25,50$ or $100 \mathrm{mM}$ TA, respectively. All lethals occurred as single mutations in both TA-treated and negative control groups. The data recorded in Table II provide similar results on the induction of SLRLs in adult males treated with the same three concentrations of TA. The results summarized in Tables I and $I I$ demonstrate that feeding of TA to larvae as well as to adults had no genotoxic effect in germ cells. This is true for metabolically inert mature sperm (Table II, brood 1) as well as for metabolically active immature male germ cells (Table I, broods 1 and 2; Table II, brood 2).

In the RXL test, genotoxicity was assessed by four criteria: (i) complete sex-chromosome loss; (ii) partial Y chromosome loss; (iii) mosaicism for chromosome loss; and (iv) nondisjunction. Feeding of $C(1) 2, y B / y^{+} Y B^{S}$ larvae was only possible with concentrations between 10 and $25 \mathrm{mM}$, whereas for the feeding of adult males concentrations up to $200 \mathrm{mM}$ could be applied. In preliminary experiments, it was determined that these concentrations are all at or below the $\mathrm{LD}_{50}$; for this reason, large numbers of progeny were obtained in all series. The data shown in Tables III and IV demonstrate that TA treatment does not increase the occurrence of the four categories of genotoxic events after feeding of larvae or adult males. In particular, the frequencies of complete sex-chromosome loss are not significantly increased.

Therefore, none of the two male germ cell assays which measure different genetic end-points were able to detect any genotoxic activity of TA after oral treatment of adults or larvae. Early reports demonstrated hepatotoxic, cirrhogenic and/or carcinogenic activity of TA in mice, rats, rabbits and goats only when applied via the subcutaneous, intraperitoneal or intravascular routes (Baker and Handler, 1943; Korpássy, 1959, 1961). These effects were not observed when TA was given orally (Handler and Baker, 1944; Korpássy and Mosonyi, 1950). Thus, a possible genotoxic activity of TA in male
Table I. Sex-linked recessive lethal test in D.melanogaster with tannic acid fed to male larvae

\begin{tabular}{rlll}
\hline TA (mM) & \multicolumn{2}{l}{ Lethals/chromosomes [frequency $(\Phi)]^{\mathrm{a}}$} & \\
\cline { 2 - 3 } & $\begin{array}{l}\text { Brood I } \\
\text { (1 day) }\end{array}$ & $\begin{array}{l}\text { Brood } 2 \\
\text { (1 day) }\end{array}$ & $\begin{array}{l}\text { Total } \\
(2 \text { days })\end{array}$ \\
\hline 0 & $3 / 1266(0.24)$ & $4 / 1253(0.32)$ & $7 / 2519(0.28)$ \\
25 & $2 / 1617(0.12)$ & $2 / 1668(0.12)$ & $4 / 3285(0.12)$ \\
50 & $2 / 1637(0.12)$ & $3 / 1812(0.17)$ & $5 / 3449(0.14)$ \\
100 & $1 / 1545(0.06)$ & $3 / 1776(0.17)$ & $4 / 3321(0.12)$ \\
\hline
\end{tabular}

'Differences between TA treatments and negative control are not significant (Kastenbaum and Bowman, 1970).

Table II. Sex-linked recessive lethal test in D.melanogaster with tannic acid fed to adult males

\begin{tabular}{rlll}
\hline TA (mM) & \multicolumn{2}{l}{ Lethals/chromosomes [frequency $(\%)]^{2}$} & \\
\cline { 2 - 3 } & $\begin{array}{l}\text { Brood } 1 \\
\text { (3 days) }\end{array}$ & $\begin{array}{l}\text { Brood } 2 \\
\text { (2 days) }\end{array}$ & $\begin{array}{l}\text { Total } \\
(5 \text { days })\end{array}$ \\
\hline 0 & $3 / 1873(0.16)$ & $3 / 1841(0.16)$ & $6 / 3714(0.16)$ \\
25 & $3 / 1475(0.20)$ & $1 / 1496(0.07)$ & $4 / 2971(0.13)$ \\
50 & $5 / 1387(0.36)$ & $4 / 1564(0.26)$ & $9 / 2951(0.30)$ \\
100 & $3 / 1456(0.21)$ & $1 / 1518(0.07)$ & $4 / 2974(0.13)$ \\
\hline
\end{tabular}

'Differences between TA treatments and negative control are not significant (Kastenbaum and Bowman, 1970).

germ line cells might be observed only when using injection treatments.

In a second series of experiments TA was assayed in somatic cells of the wing imaginal disk by feeding of larvae derived from the high bioactivation cross. This recently developed high bioactivation cross produces larvae which possess constitutively increased cytochrome P-450-dependent enzyme activities and therefore make the wing spot test more sensitive for the detection of promutagens and procarcinogens (Graf and Singer, 1992; Graf and van Schaik, 1992). The data on the induction of somatic mutation and mitotic recombination are recorded in Table $\mathrm{V}$, together with a laboratory historic control series for comparison purposes. Two separate experiments of identical size were performed. TA was quite toxic for these larvae: only a few flies survived at a concentration of $70 \mathrm{mM}$, and $50 \mathrm{mM}$ was the highest testable concentration. In the first experiment, positive results were obtained for the 25 and $50 \mathrm{mM}$ series, with the $10 \mathrm{mM}$ series giving an inconclusive diagnosis. In the second experiment, only the $50 \mathrm{mM}$ series gave a positive result, the remaining ones again being inconclusive. Pooling of the two identical experiments results in sample sizes of 120 wings per series, which is sufficient for optimal statistical conditions (Frei and Würgler, 1995). After pooling, all three concentrations gave a positive result. However, the dose-response observed is rather weak. The dose-response relationships for each experiment and for the pooled data are shown in Figure 1. A levelling-off of the genotoxic effects at the highest concentration is observed, which may be due to limited bioactivation capacity at higher concentrations. Furthermore, the data presented in Table $\mathrm{V}$ show that the genotoxic effects are mainly due to increases in the frequencies of the small single spots, with the large single spots and the twin spots remaining mostly unaffected. Small single spots may either be the consequence of genotoxic events occurring very late in larval development or they may be due 
Table III. Sex-chromosome loss test in D.melanogaster with tannic acid fed to male larvae

\begin{tabular}{|c|c|c|c|c|c|c|c|c|c|c|c|c|c|c|}
\hline \multirow[t]{2}{*}{$\mathrm{TA}(\mathrm{mM})$} & \multicolumn{7}{|c|}{ Brood $1(1 \text { day })^{2}$} & \multicolumn{7}{|c|}{ Brood $2(1 \text { day })^{2}$} \\
\hline & Fem. & Male & $\mathrm{CL}$ & PL & $M$ & ND & $\mathrm{CL}^{\mathrm{b}}(\%)$ & Fem. & Male & CL & PL & $\mathbf{M}$ & ND & $\mathrm{CL}^{\mathrm{b}}\left(\Phi_{0}\right)$ \\
\hline 0 & 2753 & 2225 & 45 & 5 & 9 & 4 & 1.61 & 2128 & 1672 & 41 & 3 & 3 & 3 & 1.89 \\
\hline 10 & 3175 & 2420 & 69 & 1 & 4 & 2 & 2.13 & 2135 & 1784 & 33 & 1 & 5 & 5 & 1.52 \\
\hline 15 & 3372 & 2821 & 78 & 3 & 16 & 6 & 2.26 & 2298 & 2003 & 57 & 2 & 4 & 4 & 2.42 \\
\hline
\end{tabular}

Abbreviations: Regul. prog., regular progeny (females and males); Exceptional prog., exceptional progeny; CL, complete loss; PL, partial loss; M, mosaicism; ND, non-disjunction in male.

'Differences between treatments and control are not significant (Kastenbaum and Bowman, 1970).

${ }^{b}$ Complete loss calculated as percentage of regular females plus $\mathrm{CL}$.

Table IV. Sex-chromosome loss test in D.melanogaster with tannic acid fed to adult males

\begin{tabular}{|c|c|c|c|c|c|c|c|c|c|c|c|c|c|c|}
\hline \multirow[t]{2}{*}{$\mathrm{TA}(\mathrm{mM})$} & \multicolumn{7}{|c|}{ Brood 1 (1 day $)^{n}$} & \multicolumn{7}{|c|}{ Brood $2(1 \text { day })^{a}$} \\
\hline & Fem. & Male & $\mathrm{CL}$ & PL & $\mathbf{M}$ & ND & $\mathrm{CL}^{\mathrm{b}}(\%)$ & Fem. & Male & $\mathrm{CL}$ & PL & $\mathbf{M}$ & ND & $\mathrm{CL}^{\mathrm{b}}\left(\phi_{0}\right.$ \\
\hline 0 & 4037 & 4663 & 75 & 3 & 8 & 4 & 1.82 & 3207 & 3266 & 52 & 4 & 7 & 6 & 1.60 \\
\hline 50 & 4590 & 5025 & 94 & 2 & 6 & 10 & 2.01 & 3286 & 3350 & 52 & 2 & 6 & 7 & 1.56 \\
\hline 100 & 5297 & 5641 & 106 & 0 & 5 & 12 & 1.96 & 3599 & 3366 & 64 & 0 & 10 & 8 & 1.75 \\
\hline
\end{tabular}

Abbreviations: Regul. prog., regular progeny (females and males); Exceptional prog., exceptional progeny; CL, complete loss; PL, partial loss; M, mosaicism; ND, non-disjunction in male.

'Differences between treatments and control are not significant (Kastenbaum and Bowman, 1970).

${ }^{b}$ Complete loss calculated as percentage of regular females plus CL.

Table V. Wing spot data obtained after exposure of $O R R / 4 ; m w h f r^{+} / m w h^{+} f r^{3}$ trans-heterozygous larvae of D.melanogaster with tannic acid

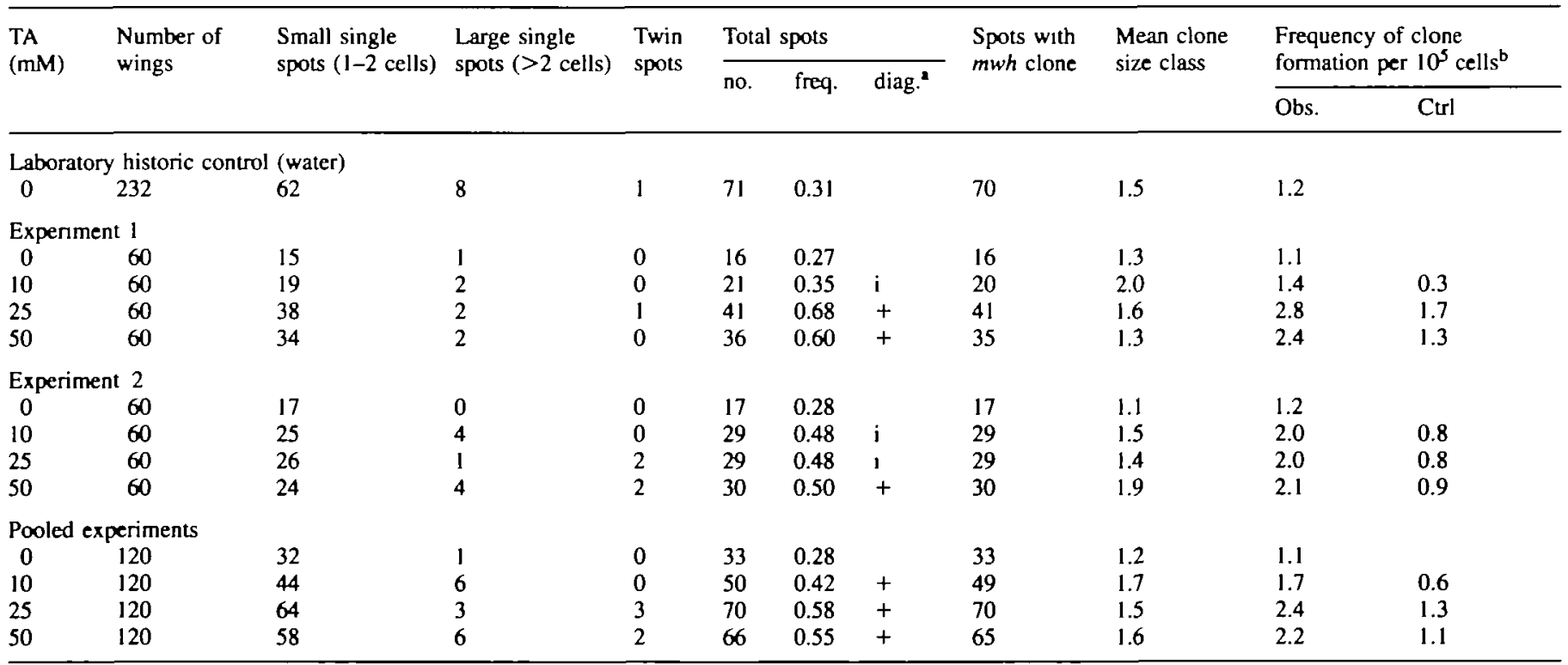

Abbreviations: Obs., observed; Ctrl, control corrected.

'Statistical diagnoses according to Frei and Würgler (1988): +, positive; $i$, inconclusive; multiplication factor $m=2$. Kastenbaum-Bowman tests, two-sided. Probability levels: $\alpha=\beta=0.05$.

${ }^{b}$ Frequency of clone formation: mwh clones/wings $/ 24400$ cells (without size correction).

to cells with partial aneuploidies which do not divide normally (Frei et al., 1992a). All in all, the results demonstrate that TA has a weak genotoxic activity in high bioactivation larvae of the wing spot test. These positive results are in line with those reported by Szakmary and Knasmüller (1991) who also found genotoxic activity of TA in somatic cells using the white/ white $^{+}$eye spot test. In their experiments, however, treatments with TA $(2.5-15 \mathrm{mmol} / \mathrm{l})$ resulted in a moderate and dose- 


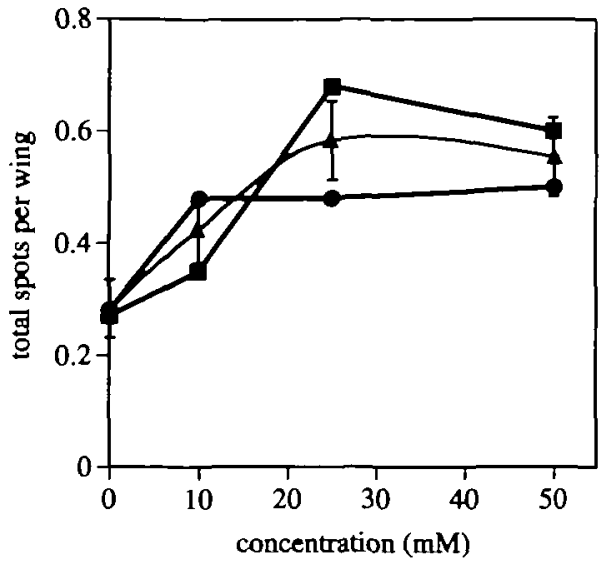

Fig. 1. Somatic mutation and recombination test. Dose-response relationships for total spots per wing after chronic treatments $(48 \mathrm{~h})$ with different concentrations of tannic acid. Squares, experiment 1; circles, experiment 2 ; triangles, pooled data (bars, standard error of the mean).

dependent induction of mosaic spots. One can assume that the genetic background of the larvae used for treatment has an influence on the genotoxic activity of TA. The strains of the eye and the wing spot tests have different genetic backgrounds, and this may explain the difference in the responses.

Szakmary and Knasmuller (1991) observed a pronounced synergistic effect of TA on mutagenicity when administered simultaneously with methyl methanesulphonate (MMS), 4nitro-quinoline- $N$-oxide (4NQO) and $c i s$-platinum ( $c i s$-DDP) to male larvae. In a recent study, Knasmüller et al. (1992) used the Tradescantia micronucleus assay to demonstrate that TA alone has a clastogenic effect and a synergistic effect when combined with $\mathrm{X}$-ray treatment. The synergistic effects observed are rather unexpected since, in the literature, desmutagenic (Stich et al., 1982; Conney, 1982; Huang et al., 1985; Das et al., 1987) or bio-antimutagenic effects (Shimoi et al., 1985; Sasaki et al., 1988, 1989, 1990; Ito et al., 1989; Imanishi et al., 1991) of TA have been reported. However, in a recent study we have also demonstrated that TA (from the same source as in the present experiments) displays a significant co-mutagenic action on the frequency of sex-chromosome losses when females exposed to different TA concentrations were crossed with mitomycin-C (MMC)-treated males carrying a ring-X chromosome (Cunha et al., 1994). This finding shows that, although TA has no clastogenic activity in D.melanogaster germ cells, it has a potentiating effect on MMC-induced damage in sperm DNA.

We conclude that TA may show mutagenic, co-mutagenic, des-mutagenic or bio-antimutagenic activity, depending on the particular experimental situation. It is well known that TA is composed of different moieties (Versole and Delahaye, 1983; Hagerman and Butlon, 1989; Hagerman et al., 1993). Actually, tannic acids from different commercial sources behaved differently toward various tannin assays (redox, metal complexing and protein precipitation assays). Different structures of the tannin moieties in the various preparations of TA may lead to different physico-chemical properties that affect the response in biological test systems (Makkar and Becker, 1993). Chemical diversity may explain the controversial results obtained with respect to the mutagenic and/or antimutagenic action of TA. It seems that a comparative evaluation of the biological effects of TA from different sources would be indicated. TA from our source may also be non-genotoxic or co-mutagenic depending on the experimental protocol and assay system used. The antimutagenic and anticarcinogenic properties of TA require further evaluation to determine the possible risks and/or protective potentials that could be associated with the exposure of living organisms to this compound.

\section{Acknowledgements}

This work was supported by the following Brazilian agencies: Conselho Nacional de Desenvolvimento Cientrfico e Technológico (CNPq), Financiadora de Estudos e Projetos (FINEP), and Pro-Reitoria de Pesquisa e Pós-Graduação da UFRGS.

\section{References}

Baker,R.D. and Handler,P. (1943) Animal experiments with tannic acid. Ann. Surgery, 118, 417-426.

Bichel.J. and Bach,A. (1968) Investigation on the toxicity of small chronic doses of tannic acid with special reference to possible carcinogenicity. Acta Pharmacol. Toxicol., 26, 41-45.

Conney,A.H. (1982) Induction of microsomal enzymes by foreign chemicals and carcinogenesis by polycyclic aromatic hydrocarbons. G.H.A. Clowes Memorial Lecture. Cancer Res., 42, 4875-4917

Cunha,K.S., Reguly,M.L., Gimmler-Luz,M.C., Hertzog Santos,J , Lehmann,M. and Rodrigues de Andrade,H.H. (1994) Co-mutagenic effect of tannic acid on ring-X chromosome loss induced by mitomycin $\mathrm{C}$ in sperm cells of Drosophila melanogaster. Mutat. Res., 308, 143-148.

Das,M., Khan,W.A., Asokan,P., Bickers,D.R. and Mukhtar,H. (1987) Inhibition of polycyclic aromatic hydrocarbon-DNA adduct formation in epidermis and lungs of SENCAR mice by naturally occurring plant phenols. Cancer Res., 47, 767-773.

Enomoto,M. (1987) Naturally occurring carcınogens of plant origin: tannıns (tannic acid). Bioact. Mol., 2, 161-166.

Frel,H. and Wurgler,F.E. (1988) Statistical methods to decide whether mutagenicity test data from Drosophila assays indicate a positıve, negative, or inconclusive result. Mutat. Res., 203, 297-308.

Frei,H. and Wurgler,F.E. (1995) Optimal experimental design and sample size for the statistical evaluation of data from Somatic Mutation And Recombination Tests (SMART) in Drosophila. Mutat Res., in press.

Frei,H., Clements.J., Howe,D. and Wurgler,F.E. (1992a) The genotoxicity of the anti-cancer drug mitoxantrone in somatic and germ cells of Drosophila melanogaster. Mutat. Res., 279, 21-33.

Frei,H., Lilthy,J., Brauchli,J., Zweifel,U., Wurgler,F.E. and Schlatter,C. (1992b) Structure/activity relationships of the genotoxic potencies of sixteen pyrrolizidine alkaloids assayed for the induction of somatic mutation and recombination in wing cells of Drosophila melanogaster. Chem-Biol. Interact., 83, 1-22.

Graf,U. and Singer,D. (1992) Genotoxicity testing of promutagens in the wing somatic mutation and recombination test in Drosophila melanogaster. Rev. Int. Contam. Ambient., 8, 15-27.

Graf,U. and van Schaik,N. (1992) Improved high bioactivation cross for the wing somatic mutation and recombination test in Drosophila melanogaster. Mutat. Res., 271, 59-67.

Graf,U., Würgler,F.E., Katz,A.J., Frei,H., Juon,H., Hall,C.B. and Kale,P.G. (1984) Somatic mutation and recombination test in Drosophila melanogaster. Environ. Mutagen., 6, 153-188.

Graf,U., Frei,H., Kägi,A., Katz,A.J. and Würgler,F.E. (1989) Thirty compounds tested in the Drosophila wing spot test. Mutat. Res., 222, 359-373.

Hagerman,A.E. and Butlon,L.J. (1989) Choosing appropriate methods and standards for assaying tannin. J. Chem Ecol., 15, 1795-1810.

Hagerman,A.E., Robbins,C.P., Weekrasuriya,Y., Wilson,T.C. and McArthur,C. (1993) Tannin chemistry in relation to digestion. J. Range Manage., 45, $57-62$.

Handler,P. and Baker,R.D. (1944) The toxicity of orally administered tannic acid. Science, 99, 393.

Hartman,P.E. and Shankel,D.M. (1990) Antimutagens and anticarcinogens: a survey of putative interceptor molecules. Environ. Mol Mutagen., 15, 145-182.

Huang,M.T., Wood,A.W., Newmark,H.L., Sayer,J.M., Yagi,H., Jerina,D.M. and Conney,A.H. (1983) Inhibition of the mutagenicity of bay-region diolepoxides of polycyclic aromatic hydrocarbons by phenolic plant flavonoids. Carcinogenesis, 4, 1631-1637.

Huang,M.T., Chang,R.L., Wood,A.W., Newmark,H.L., SayerJ.M., Yagi,H., Jerina,D.M. and Conney,A.H. (1985) Inhibition of the mutagenicity of bayregion diol-epoxides of polycyclic aromatic hydrocarbons by tannic acid, hydroxylated anthraquinones and hydroxylated cinnamic acid derivatives. Carcinogenesis, 6, 237-242. 
Imanishı,H., Sasak,,Y.F,, Ohta,T., Watanabe,M., Kato,T. and Shirasu,Y. (1991) Tea tannin components modify the induction of sister-chromatid exchanges and chromosome aberrations in mutagen-treated cultured mammalian cells and mice. Mutat. Res., 259, 79-87.

International Agency for Research on Cancer (IARC) (1976) Tannic acid and tannins. IARC Monographs on the Evaluation of Carcinogenic Risk of Chemicals to Man. Some Naturally Occurring Substances. IARC Scientific Publications, Lyon, France, vol. 10, pp. 253-262.

Ito,Y., Ohnıshi,S and Fujie,K. (1989) Chromosome aberrations induced by aflatoxin $B_{1}$ in rat bone marrow cells in vivo and their suppression by green tea. Mutat. Res., 222, 253-261.

Kastenbaum,M.A. and Bowman,K.O. (1970) Tables for determining the statistical significance of mutation frequencies. Mutat. Res., 9, 527-549.

Kirby,K.S. (1960) Induction of tumours by tannin exuracts. Br. J. Cancer, 14, 147-153.

Knasmuller,S., Kim,T.-W. and Ma,T.-H. (1992) Synergıstic effect between tannic acid and $\mathrm{X}$-rays detected by the Tradescantia-micronucleus assay. Mutat. Res., 270, 31-37.

Korpássy,B. (1959) The hepatocarcinogenicity of tannic acid. Cancer Res., $19,501-507$.

Korpássy,B. (1961) Tannıns as hepatic carcinogens. Progr. Exp. Tumor Res., 2, 245-290.

Korpássy,B. and Mosonyi,M. (1950) The carcinogenic activity of tannic acid. Liver tumours induced in rats by prolonged subcutaneous administration of tannic acid solutions. Br. J. Cancer, 4, 411-420.

Lindsley,D.L. and Zimm,G.G. (eds) (1992) The genome of Drosophila melanogaster. Academic Press, San Diego,CA.

Makkar,H.P.S. and Becker,K. (1993) Behavior of tannic acid from various commercial sources towards redox, metal complexing and protein precipitation assays of tannins. J. Sci. Food Agric., 62, 295-299.

Ramel,C., Alekperov,U K., Ames,B.N., Kada,T. and Wattenberg,L.W. (1986) Inhibitors of mutagenesis and their relevance to carcinogenesis. Mutat. Res., $168,47-65$.

Sasaki,Y.F., Imanıshi,H., Ohta, T., Watanabe,M., Matsumoto,K. and Shirasu,Y (1988) Suppressing effect of tannic acid on UV and chemically induced chromosome aberrations in cultured mammalıan cells. Agric. Bıol. Chem., 52, 2423-2428.

Sasaki,Y.F., Imanishi,H., Ohta,T., Watanabe,M., Matsumoto,K. and Shirasu,Y. (1989) Suppressing effect of tannic acid on the frequencies of mutageninduced sister-chromatid exchanges in mammalian cells. Mutat. Res., 213, 195-203.

Sasaki,Y.F., Matsumoto,K., Imanishi,H., Watanabe,M., Ohta,T., Shirasu,Y. and Tutikawa,K. (1990) In vivo anticlastogenic and antimutagenic effects of tannic acid in mice. Mutat. Res., 244, 43-47.

Sharna,G.P., Sobti,R.C. and Sahi,K. (1982) Effects of some carcinogens on hemopoietic ussue of Ratrus norvegicus. Nucleus Calcutta, 25, 142-147.

Shimoi,K., Nakamura, Y., Tomıta,I. and Kada,T. (1985) Bio-antimutagenic effects of tannic acid on UV and chemically induced mutagenesis in Escherichia coli B/r. Mutat. Res., 149, 17-23.

Stich,H.F. and Dunn,B.P. (1986) Relationship between cellular levels of beta carotene and sensitivity to genotoxic agents. Int. J. Cancer, 38, 713-717.

Stich,H.F and Rosin,M. (1984) Naturally occurring phenolics as antimutagenic and anticarcinogenic agents. In Friedman,M. (ed.), Nutritional and Toxicological Aspects of Food Safery. Plenum Press, New York, pp. 1-29.

Stich,H.F., Rosin,M.P. and Bryson,L. (1982) Inhibition of mutagenicity of a model nitrosation reaction by naturally occurring phenolics, coffee and tea. Mutat. Res., 95, 119-128.

Szakmary,A. and Knasmuller,S. (1991) Effects of tannic acid on spontaneous and induced somatic mutations in Drosophila melanogaster. Mutagenesis, 6, 225-228.

Valencia,R., Mason,J.M. and Zimmering,S. (1989) Chemical mutagenesis testing in Drosophila. VI. Interlaboratory comparison of mutagenicity tests after treatment of larvae. Environ. Mol. Mutagen., 14, 238-244.

Versole,M. and Delahaye, P. (1983) Analysis of tannic acid by highperformance liquid chromatography. J. Chromatogr., 268, 469-476.

Würgler,F.E., Sobels,F.H. and Vogel,E. (1984) Drosophila as an assay system for detecting genetic changes. In Kilbey, BJ., Legator,M., Nichols, W. and Ramel,C. (eds), Handbook of Mutagenicity Test Procedures, 2nd edn. Elsevier, Amsterdam, pp. 555-601.

Received on May 23, 1994; accepted on March 7, 1995 